\title{
New species of Trachycorystes Bleeker, with comments on other species of the genus (Ostariophysi: Siluriformes: Auchenipteridae)
}

\author{
Heraldo A. Britski ${ }^{1}$ and Alberto Akama ${ }^{2}$
}

A new species of Trachycorystes from the rio Aripuanã, above Dardanelos and Andorinhas falls, is described. The new species is distinguished from the only other species of the genus, T. trachycorystes, by the following characteristics: jaws of equal length ( $v s$. lower jaw prognathous in T. trachycorystes); skull roof covered by thick ( $v s$. thin) integument; inner mental barbel very thin and short not reaching base of outer barbel ( $v s$. extending to or beyond base of outer mental barbel); dorsal-fin spine serrated posteriorly, smooth or rough anteriorly ( $v s$. serrated anteriorly and smooth or rough posteriorly); caudal fin shallowly forked (vs. emarginate); and gas bladder simple, without diverticula (vs. with three posterior diverticula). Comments and data on the nominal species Trachycorystes trachycorystes are provided. Trachycorystes cratensis Miranda Ribeiro, 1937, is allocated to the genus Trachelyopterus Valenciennes, 1840, and another local catfish species, Parotocinclus aripuanensis Garavello, 1988 , has its type locality reassigned.

Descreve-se uma espécie nova de Trachycorystes proveniente do curso superior do rio Aripuanã, acima das cachoeiras Dardanelos e Andorinhas. A espécie nova diferencia-se da outra espécie do gênero, T. trachycorystes, pelos seguintes caracteres: maxilas de mesmo comprimento, isto é, mandíbula não prognata (vs. mandíbula prognata em T. trachycorystes); teto do crânio coberto com pele espessa (vs. fina); barbilhão mental muito fino e curto não alcançando a base do barbilhão pós-mental (vs. estendendo-se até a base do barbilhão pós-mental ou além); espinho da nadadeira dorsal com a borda anterior lisa ou rugosa e a posterior com serras retrorsas ( $v s$. borda anterior com serras e a posterior lisa ou rugosa); nadadeira caudal bifurcada ( $v s$. emarginada); bexiga natatória simples, sem divertículos ( $v s$. com três divertículos posteriores). Comentários e dados sobre as outras espécies nominais de Trachycorystes são apresentados. Trachycorystes cratensis Miranda Ribeiro, 1937, é transferido para o gênero Trachelyopterus Valenciennes, 1840, e retificam-se dados sobre a localidade-tipo de Parotocinclus aripuanensis Garavello, 1988.

Key words: Biodiversity, Parotocinclus aripuanensis, Rio Aripuanã, Trachycorystes cratensis, Trachelyopterus.

\section{Introduction}

In 1976 Wolfgang J. Junk, director of the graduate course on Freshwater Biology and Fisheries (Biologia de Água Doce e Pesca Interior) at the Instituto Nacional de Pesquisas da Amazônia (INPA), organized an expedition that included ichthyologists Jacques Géry, Naércio A. Menezes, and Heraldo A. Britski, and eleven students and fishermen to the rio Aripuanã, a clearwater tributary of the rio Madeira, Mato Grosso State, Brazil. The portion of the rio Aripuanã surveyed included two large waterfalls, "Andorinhas" and "Dardanelos", nearby the city of Aripuanã ( $\left.10^{\circ} 10^{\prime} \mathrm{S} 59^{\circ} 27^{\prime} \mathrm{W}\right)$. From 6 to 18 November the expedition explored the rio Aripuanã as well as its small tributaries, both above and bellow the waterfalls. At that time it was quite noticeable that the fish fauna above the waterfalls was distinct from the fauna below, indicating that the falls act as an effective barrier to the movement of fishes in both directions. On the basis of material collected above the falls several new fishes were described, including Inpaichthys kerri, a new species and genus of Characidae proposed by Géry \& Junk (1977).

The Aripuanã collection was initially vouchered at INPA, but in 1979 part of the siluriforms was donated to MZUSP. Among the auchenipterids collected from the upper portion of the rio Aripuanã some looked quite peculiar upon first examination and seemed representative of a new taxa. Years later, Akama (2004) examined those specimens in connection with his phylogenetic studies of Auchenipteridae and allocated the new species described herein to the genus Trachycorystes.

${ }^{1}$ Museu de Zoologia da Universidade de São Paulo. Av. Nazaré, 481, 04264-000 São Paulo, SP, Brazil.

${ }^{2}$ NEAMB UFT. Núcleo de Estudos Ambientais, Universidade Federal do Tocantins. 
The genus Trachycorystes was proposed by Bleeker (1858) and currently contains four nominal species (Reis et al., 2003; Ferraris, 2007): T. trachycorystes (Valenciennes, 1840: 214) (Type locality Brésil [= Brazil]), T. typus Bleeker, 1862: 6. (Type locality Brésil [= Brazil]), T. obscurus (Günther, 1863: 442)(Type locality: the Essequibo, British Guiana [= Guyana]), and $T$. cratensis Miranda Ribeiro, 1937: 55. (Type locality rio Granjeiro, Crato, Ceará [Brazil]).

Trachycorystes typus Bleeker (1862) represents an unneeded replacement name for Auchenipterus trachycorystes Valenciennes, 1840, and is therefore a synonym of T. trachycorystes. Trachycorystes obscurus is considered a junior synonym of T. trachycorystes (Ferraris, 2007). Trachycorystes cratensis is properly placed in the genus Trachelyopterus as demonstrated in this paper. Thus, $T$. trachycorystes is considered the only valid species of the genus, and is distinguished from the new species of Trachycorystes described herein.

\section{Material and Methods}

A total of 81 specimens of the new species of Trachycorystes was examined of which 22 were measured and counted for comparison to 10 specimens of $T$. trachycorystes. Procedures for taking measurements and counts follow Greenfield \& Glodek (1977) except for body depth, which was measured at dorsal-fin origin. Standard length (SL) is expressed in $\mathrm{mm}$ and other measurements as either percentage of standard length (SL) or of head length (HL). Measurements and counts were taken on the left side of the specimen whenever possible. Meristic data are given in the description followed by the number of specimens for each count in parentheses when variable (counts for holotype denoted by asterisk). Vertebral counts were taken only from dry skeleton (sk) and cleared and stained (c\&s) material prepared according to procedures of Taylor \& van Dyke (1985); vertebrae of the Weberian apparatus were counted as six elements, and are included in the total vertebral count; the fused PU1+U1 of the caudal region was counted as a single element. Institutional abbreviations follow Ferraris (2007).

\section{Results \\ Trachycorystes menezesi, new species Fig. 1}

Holotype. MZUSP 104671, 185.7 mm SL, igarapé do Aeroporto, right bank tributary of rio Aripuanã, Aripuanã, Mato Grosso State, Brazil, 9 Nov 1976, Equipe Ictiologia INPA.

Paratypes. Brazil, Mato Grosso State, Município de Aripuanã: MZUSP 37601, 62, 32.7-160.0 mm SL, 1 c\&s, same data as holotype. INPA 35313, 5, 71.2-155.2 mm SL, same data as holotype. ANSP 191672, 5, 53.5-124.4 mm SL, same data as holotype. MZUSP 63287 4, 179.1-199.2 mm SL, igarapé Genipapo, right bank tributary of rio Aripuanã, $70 \mathrm{~km}$ above Dardanelos and Andorinhas falls, 14 Nov 1976, Equipe Ictiologia INPA. MZUSP
104672, 3, 151.6-189.3, rio Aripuanã, 2 km above Dardanelos and Andorinhas falls, near Cachoeira dos Patos, 13 Oct 2005, Francisco Machado.

Diagnosis. Trachycorystes menezesi can be distinguished from its sole congener $T$. trachycorystes by having: jaws equal in length ( $v s$. lower jaw longer, prognathous in $T$. trachycorystes); skull roof covered by thick integument concealing bony sculptures (vs. skull roof covered by thin integument, bony sculptures visible); inner mental barbel thin and very short, not reaching base of outer mental barbel ( $v s$. inner mental barbel thicker, extending to or beyond base of outer mental barbel); dorsal-fin spine serrated only along posterior margin ( $v s$. dorsal-fin spine serrated only along anterior margin); caudal fin weakly forked (vs. emarginate); gas bladder simple, without diverticula ( $v s$. gas bladder with three posterior diverticula, one medial and paired posterolateral).

Description. Morphometrics presented in Table 1. Body short, stout, approximately round in cross section in front of dorsalfin origin, compressed at caudal peduncle. Head about as wide as long, depressed anteriorly; interorbital region slightly convex in frontal view. Dorsal profile strongly convex from upper lip to second nostril; straight, ascending gradually from that point to dorsal-fin origin; shallowly convex from dorsal fin to adipose fin; shallowly concave from adipose fin to caudal fin. Ventral profile convex from lower lip to anal fin, belly more or less protruded depending on stomach repletion; straight, gradually ascending along anal-fin base and concave between anal and caudal fins.

Integument on skull roof relatively thick, concealing bony sculptures. Facial and opercular bones also covered with somewhat thick integument. Posterior cleithral process long, reaching two thirds of pectoral-spine length, dorsal margin partially covered by integument, surface longitudinally striated, ventral portions covered by very thin integument.

Jaws equal, lower jaw not protruding. Mouth terminal, wide, posterior angle aligned with vertical through anterior margin of eye. Premaxillary tooth patch rounded laterally, without posteriorly projected angle. Dentary tooth patch laterally with angle projected posteriorly. Viliform teeth distributed in about eight series in each premaxillary and dentary patch. Branchiostegal membranes broadly attached to isthmus. Gill opening reduced, not extending ventrally to base of pectoral-fin spine. Gill arches covered by somewhat thick integument, without gill-rakers. Eye lateral; moderately inclined anteromedially and covered by integument (orbital margin not free). Anterior nostril tubular; posterior nostril with a small medial flap. Fontanel elliptical, elongated longitudinally, situated between dorsal margins of orbits.

Barbels slightly flattened dorsoventrally. Maxillary barbel short, extending to pectoral-fin spine or slightly beyond its base, not surpassing pectoral-fin base. Basal portion of maxillary barbel sheltered in deep groove bellow eye that becomes gradually shallower toward opercular area. Outer 


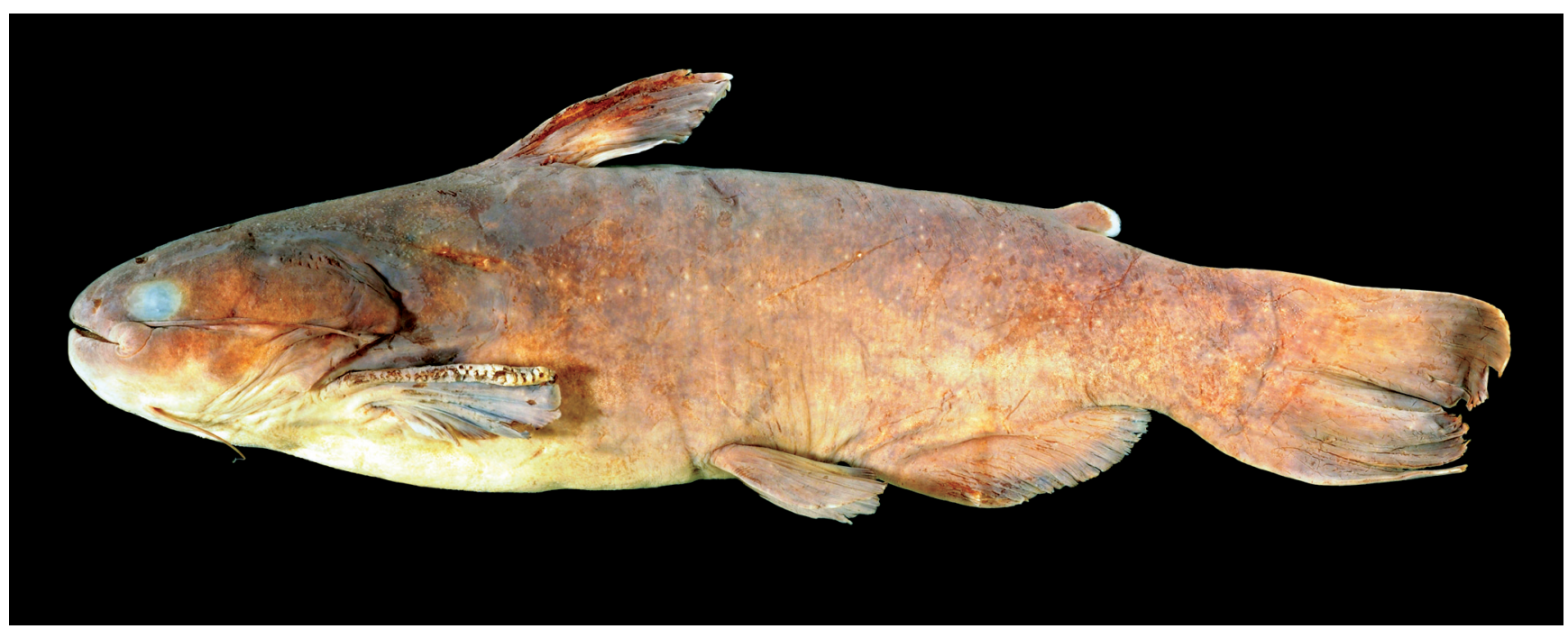

Fig. 1. Trachycorystes menezesi, new species, MZUSP 104671, holotype, 185.7 mm SL. Igarapé do Aeroporto, right bank tributary of rio Aripuanã, Aripuanã, Mato Grosso State, Brazil.

mental barbel short, extending half the distance from its base to pectoral-fin base. Inner mental barbel very thin and short, not reaching base of outer mental barbel.

Lateral line pores extending along sides to caudal-fin base and conspicuous due to accompanying white (despigmented) points; about eight vertical columns of white points along body; columns extending to near dorsal profile, shorter ventrally.

Dorsal fin roughly triangular, its origin at vertical through tip of posterior cleithral process. Dorsal-fin rays I+6. Dorsalfin spine shorter than first two or three branched rays. Anterior margin of dorsal spine smooth or rough, not serrated; posterior margin with 5 to 24 retrorse serrations (number increasing with size of specimen). Adipose fin short, teardrop shaped with posterior base at vertical through base of last anal-fin ray. Pectoral fin roughly triangular, its origin just posterior to gill opening. Pectoral-fin rays I+7. Ossified portion of pectoral spine same length or shorter than first branched rays. Tip of spine with minute unossified segmented portion; spine finely striated above and below and with well developed serrations along entire anterior and posterior margins; anterior margin with 20-31 conical antrorse serrations; posterior margin with 13-26 retrorse serrations enlarged distally; postero-lateral border of each serration with two or three minute spines. Posterior margin of depressed pectoral fin distant from pelvicfin origin. Pelvic fin roughly ovoid. Pelvic-fin base posterior to vertical through posterior insertion of dorsal fin. Pelvic-fin rays $i+8$. Pelvic-fin posterior margin rounded, reaching analfin origin. Anal-fin base long, distal margin straight to shallowly convex. Anal-fin rays iii,16 (4*), iii,17 (10), iii,18 (7) or iii,19 (2), first branched anal-fin ray about three times as long as last one. Caudal fin bilobed, weakly forked; upper lobe slightly longer than lower. Principal caudal-fin rays $i+7+8+i$; procurrent caudal-fin rays (counted in one c\&s specimen): 18 dorsal; 20 ventral. Total vertebrae 41 . Branchiostegal rays 8 .

Table 1. Morphometrics of Trachycorystes menezesi $(\mathrm{n}=23$, ranges include holotype MZUSP 104671) and T. trachycorystes $(\mathrm{n}=10$, ranges exclude stuffed holotype MNHN A9422).

\begin{tabular}{|c|c|c|c|c|c|c|c|c|c|c|c|}
\hline \multirow{3}{*}{ St andard length (mm) } & \multicolumn{5}{|c|}{ Trachycorystes menezesi } & \multicolumn{6}{|c|}{ Trachycorystes trachycorystes } \\
\hline & \multirow{3}{*}{$\frac{\text { holotype }}{185.71}$} & \multicolumn{2}{|r|}{ ran ge } & \multirow[t]{2}{*}{ mean } & \multirow[t]{2}{*}{ SD } & \multirow{2}{*}{$\frac{\text { holotype }}{235.00}$} & \multicolumn{3}{|c|}{ range } & \multirow[t]{2}{*}{ mean } & \multirow[t]{2}{*}{ SD } \\
\hline & & 58.51 & $\begin{array}{l}-\quad 179.09 \\
\end{array}$ & & & & 108.64 & $\overline{-}$ & 246.80 & & \\
\hline \multicolumn{11}{|c|}{ Percents of st andard length } & \\
\hline Head length & 26.43 & 24.78 & 28.37 & 26.66 & 0.01 & 30.64 & 23.55 & - & 30.63 & 27.30 & 0.02 \\
\hline Body depth & 27.34 & 22.63 & 28.73 & 25.35 & 0.01 & 31.06 & 22.38 & - & 28.33 & 25.10 & 0.01 \\
\hline Caudal p eduncle depth & 12.19 & 10.77 & 13.67 & 12.07 & 0.01 & 13.40 & 11.78 & - & 14.44 & 13.05 & 0.01 \\
\hline Cleithral width & 26.84 & 25.36 & 28.32 & 26.74 & 0.01 & 33.62 & 27.95 & - & 34.29 & 31.45 & 0.02 \\
\hline Predorsal dist ance & 34.27 & 33.20 & 36.69 & 34.55 & 0.01 & 39.15 & 33.66 & - & 38.74 & 36.17 & 0.01 \\
\hline Prepelvic distance & 55.27 & $52 ; 36$ & 57.46 & 54.46 & 0.01 & 55.74 & 52.55 & - & 58.21 & 54.17 & 0.01 \\
\hline Dorsal-spine length & 19.32 & $16 ; 73$ & 22.75 & 19.34 & 0.01 & 14.30 & 18.13 & - & 25.72 & 21.64 & 0.02 \\
\hline Pectoral-spine length & 21.03 & 20.97 & 26.99 & 22.40 & 0.05 & 10.79 & 24.56 & - & 30.28 & 27.57 & 0.02 \\
\hline Pelvic-fin length & 14.73 & 13.69 & 17.45 & 15.25 & 0.01 & & 14.61 & - & 21.65 & 17.35 & 0.02 \\
\hline Anal-fin length & 19.77 & 15.82 & 20.94 & 18.08 & 0.01 & 17.19 & 14.87 & - & 22.12 & 17.38 & 0.02 \\
\hline \multicolumn{12}{|c|}{ Percents of headlength } \\
\hline Eye diameter & 15.50 & 14.58 & 28.55 & 18.57 & 0.01 & 14.58 & 13.97 & - & 19.48 & 17.45 & 0.02 \\
\hline Snout length & 38.77 & 35.24 & 44.48 & 39.15 & 0.03 & 36.11 & 33.14 & - & 45.38 & 39.44 & 0.03 \\
\hline Int erorbi tal width & 64.72 & 59.25 & 66.71 & 63.40 & 0.02 & 59.72 & 57.76 & - & 72.43 & 64.94 & 0.04 \\
\hline Mouth width & 71.91 & 59.70 & 71.91 & 65.79 & 0.03 & 70.49 & 70.25 & - & 84.90 & 76.32 & 0.05 \\
\hline
\end{tabular}


Gas bladder abbreviated cordiform (wider than long), simple (without diverticula) and with a well-developed internal T-shaped septum (Fig. 2a).

Coloration in alcohol. Head and body grayish-brown to dark brown, darker dorsally, becoming grayish-yellow or white on ventral surface; sometimes with dark irregular blotches of melanophores, giving to whole the aspect of dirty color. Dorsal, pectoral, pelvic, anal and caudal fins grayish-brown to dark brown or black, sometimes with light basal portion and darker distal portion (two portions more or less conspicuously separated); adipose fin brown with yellowish or whitish margin.

Sexual dimorphism. In males of Trachycorystes menezesi the deferent canal runs in front of the anal-fin first unbranched rays; urogenital aperture positioned at tip of first branched ray. Urogenital aperture of females opens at distal end of a very small papilla located just in front of anal-fin origin. No modifications observed in the maxillary barbel and in the dorsal-fin spine of males, as is usual in some genera of Auchenipteridae as Auchenipterus (see for example Ferraris \& Vari, 1999).

Distribution. Trachycorystes menezesi is known from the rio Aripuanã (Madeira drainage) and its tributaries above the falls of Dardanelos and Andorinhas, Mato Grosso State, Brazil (Fig. 3).

Ecological notes. Specimens of Trachycorystes menezesi were collected during the INPA expedition that took place in November 1976, during the low water period of the rio
Aripuanã and its clear water tributaries. Specimens from the rio Aripuanã were easily caught at night, using fishhooks baited with small pieces of characiform fishes and placed near the banks ( 2 or $3 \mathrm{~m}$ deep). They were also abundant in tributaries of the rio Aripuanã, such as igarapé do Aeroporto and igarapé Genipapo, clear water creeks two or three $\mathrm{m}$ wide and up to $0.6 \mathrm{~m}$ deep, with forested margins and sandy bottoms where fallen trunks, branches and vegetal detritus were abundant. Specimens were caught using deep nets and by displacing the submerged debris, the natural hiding-places of the species. Stomach and intestinal contents included mainly carapace parts of different orders of insects, as well as parts of a scorpion, a crustacean and a characiform fish; one individual had within its stomach a piece of a curimatid fish used as bait with a hook attached. In the rio Aripuanã, besides Trachycorystes menezesi, the only other large-sized predator collected was the "traíra", Hoplias malabaricus, caught in large number with fishhooks. In small creeks, besides Hoplias malabaricus, the new species was collected with a larger variety of small predators like Rhamdia quelen, Acestrorhynchus sp., Crenicichla sp., Tatia sp., and Synbranchus marmoratus. Specimens of Trachycorystes menezesi caught at night with fishhooks or gill nets emitted a guttural sound, possibly produced by its gas bladder like many other siluriforms.

Etymology. The name menezesi is given in honor of Naércio A. Menezes who participated in the INPA expedition of 1976, when the new species was collected for the first time, and for his major contributions to the scientific knowledge of the ichthyofauna of the Neotropics.

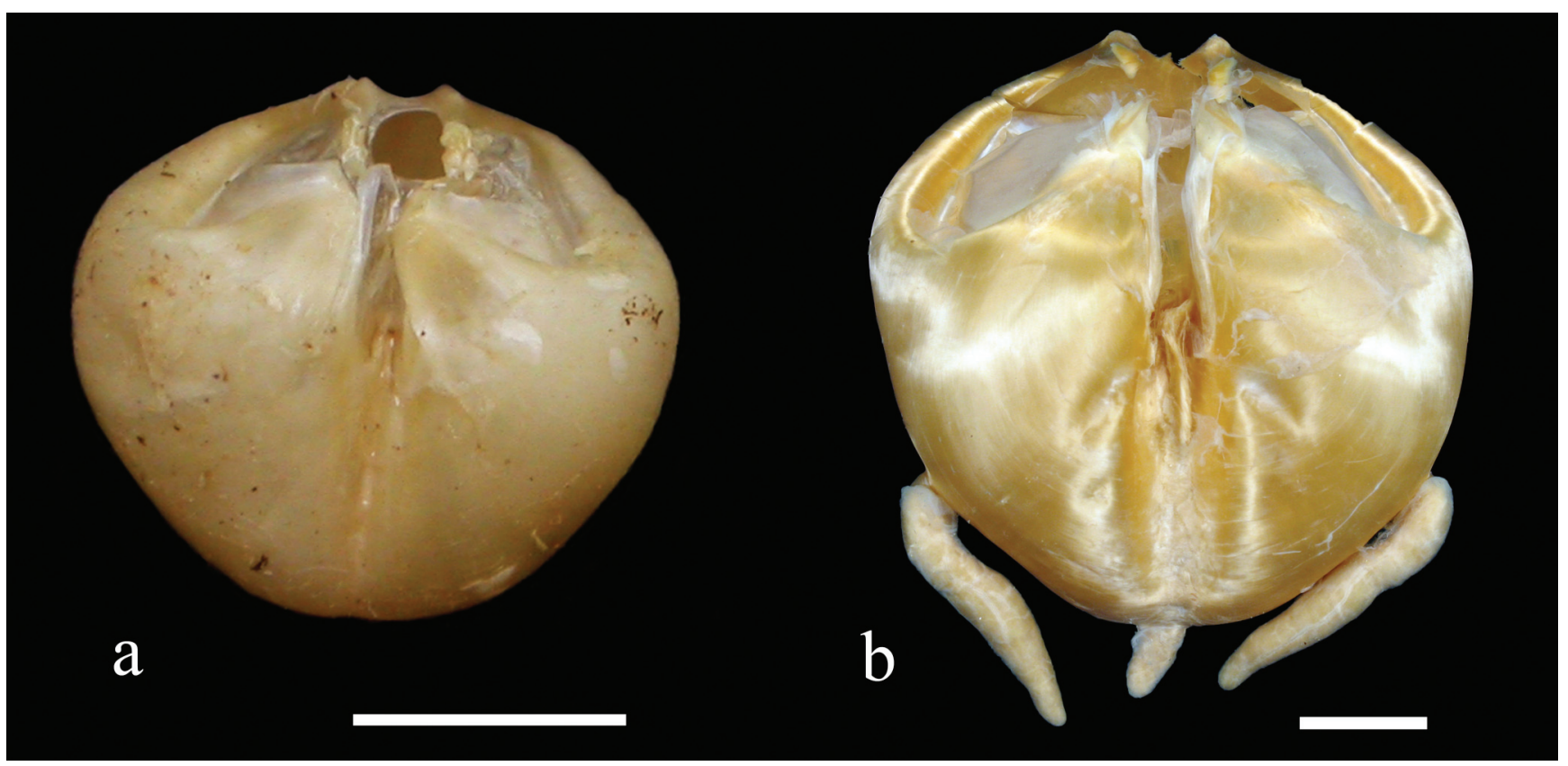

Fig. 2. Dorsal view of gas bladder of Trachycorystes menezesi, new species (a), and Trachycorystes trachycorystes (b). Scale bar $=10 \mathrm{~mm}$. 


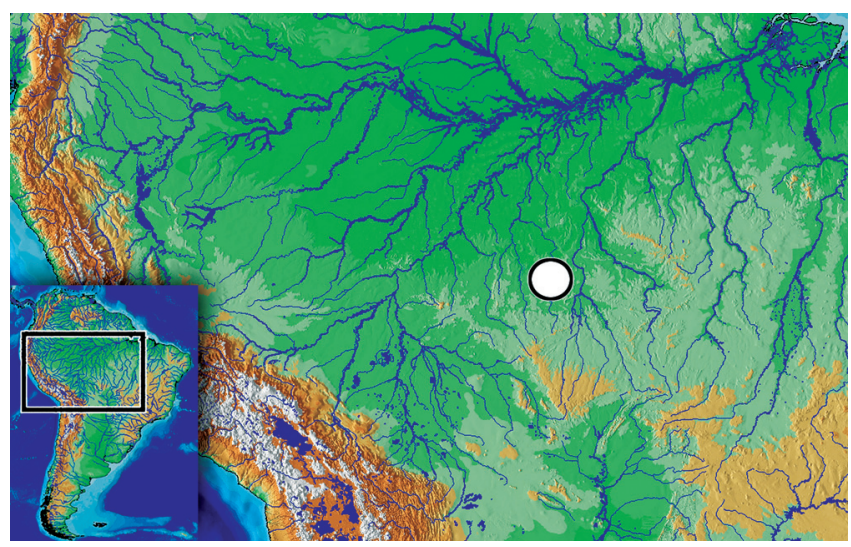

Fig. 3. Rio Aripuanã area showing the collection localities (circle) of Trachycorystes menezesi.

Remarks. According to Kullander (1995) at least ten nominal fish species are known from the upper rio Aripuanã, suggesting a high degree of endemism for this portion of the river. Noteworthy is the presence of two carnivorous species above the rio Aripuanã waterfalls, the "sapatão" or " mandubé" (Trachycorystes menezesi) and the "traíra" (Hoplias malabaricus), both of which are remarkably abundant. Both species were easily captured in large numbers in the rio Aripuanã using fishhooks during the expedition. The section of the river below the falls is dominated by the much diversified Amazonian carnivorous fishes that reach the base of the falls, but are almost completely absent in the section above the falls (H. A. Britski, pers. obs.). The large number of individuals in populations of T. menezesi (as well as of $H$. malabaricus) may be attributed to the absence of competitors above the falls of Dardanelos and Andorinhas.

Although the description of Trachycorystes menezesi is largely based on specimens collected during the INPA 1976 expedition, specimens of the new species were again obtained in 2005 from the Aripuanã River (MZUSP 104672). Recent collections made above the falls of tributaries of the Rivers Madeira, Tapajós, and Xingu, and of the Amazon proper failed to provide specimens of the new species. These facts strengthen the assumption that the new species is limited to the upper portion of the Aripuanã River basin (Fig. 3).

Kullander (1995) mentioned that Parotocinclus aripuanensis (not $P$. aripuananus as cited by Kullander 1995: 158) was collected in the rio Canumã. His statement, based on information provided by Garavello (1988) when describing that species, deserve some comments. Garavello (1988: 122) indicated the type locality of $P$. aripuanensis as "Ingazeiro, 20 km upstream of Boca do Rio Canumã, Aripuanã, MT", but gave no information about the collectors and date of collection. Since the specimen was collected during the INPA expedition to rio Aripuanã, we can now say that the type locality is correctly "igarapé Ingazeiro, tributary of the rio Canamã (not Canumã), about $20 \mathrm{~km}$ upstream of its mouth along the right bank of the rio Aripuanã, State of Mato Grosso, collected during INPA expedition, 17 November 1976". The rio Canumã (not Canamã) empties into the Paraná dos Abacaxis or Urariá, a right branch of the rio Madeira that forms the southeastern limit of the Tupinambaranas islands. In spite of this correction, Kullander's comments that the fish was collected in a river downstream of Dardanelos falls, prevails because the rio Canamã does in fact empty into the rio Aripuanã at $09^{\circ} 55^{\prime} 18^{\prime \prime} \mathrm{S} 59^{\circ} 19^{\prime} 02^{\prime \prime} \mathrm{W}$, downstream of the falls.

In a recent study Birindelli et al. (2009) reviewed the gross morphology of the gas bladder of 31 genera of Doradidae and provided a classification of the different types they found. According to that classification the gas bladder of Trachycorystes menezesi (Fig. 2a) is abbreviated cordiform simple (without diverticula) with a well-developed internal Tshaped septum. On the other hand, in T. trachycorystes the gas bladder (Fig. 2b) has three posterior diverticula, one single, well-developed and relatively short terminal diverticulum and a pair of posterolateral diverticula (one on either side), similar albeit longer than those found in Agamyxis albomaculatus (Birindelli et al., 2009: 266, fig. 4 I, J).

Trachycorystes menezesi is similar to T. trachycorystes in most morphometric features. The only apparent morphometric differences between the two species are related to cleithral width and mouth width. The cleithral width is smaller in $T$. menezesi (25.36-28.32\% of SL, mean $26.74 \%$ ) than in $T$. trachycorystes (27.95-34.29\% of SL, mean $31.45 \%$ ), and the width of mouth is again smaller in the new species (59.70$71.91 \%$ of head length, mean $65.79 \%$ ) than in T. trachycorystes (70.25-84.90\% of SL, mean $76.32 \%$ ). These two proportions indicate that $T$. menezesi is a more slender species.

In the holotype of Trachycorystes cratensis Miranda Ribeiro, 1937 (MNRJ 947), the sphenotic bone is almost rectangular, parallel to the frontals, and excluded from the orbital border. Those features are distinctive of the genus Trachelyopterus, and depart from the typical subtriangular shape of the sphenotic, which is laterally expanded and forms part of the dorsal orbital rim in Trachycorystes. Trachycorystes cratensis is thereby allocated to the genus Trachelyopterus Valenciennes, 1840.

We also examined the holotype of Auchenipterus trachycorystes Valenciennes, 1840 (MNHN A.9422) and present the morphometric data for the stuffed and dry mounted specimen (Table 1), as well as a photograph (Fig. 4). Valenciennes' (in Cuvier \& Valenciennes, 1840: 214) description is very incomplete, and no other data on the holotype is found in the literature subsequent to the original description. Additional data for Trachycorystes trachycorystes taken on 10 specimens deposited at MZUSP (See list of material) are included in Table 1.

Valenciennes' (in Cuvier \& Valenciennes, 1840: 216) description of Trachycorystes trachycorystes stated "Il vient du Cabinet de Lisbonne, et nous croyons du Brésil. [It comes from the Cabinet de Lisbonne, and we believe to be from Brazil]". The holotype represents one of the pieces taken from the Cabinet de Lisbonne when Napoleon's troops invaded Portugal in 1808 and collections of that museum were 

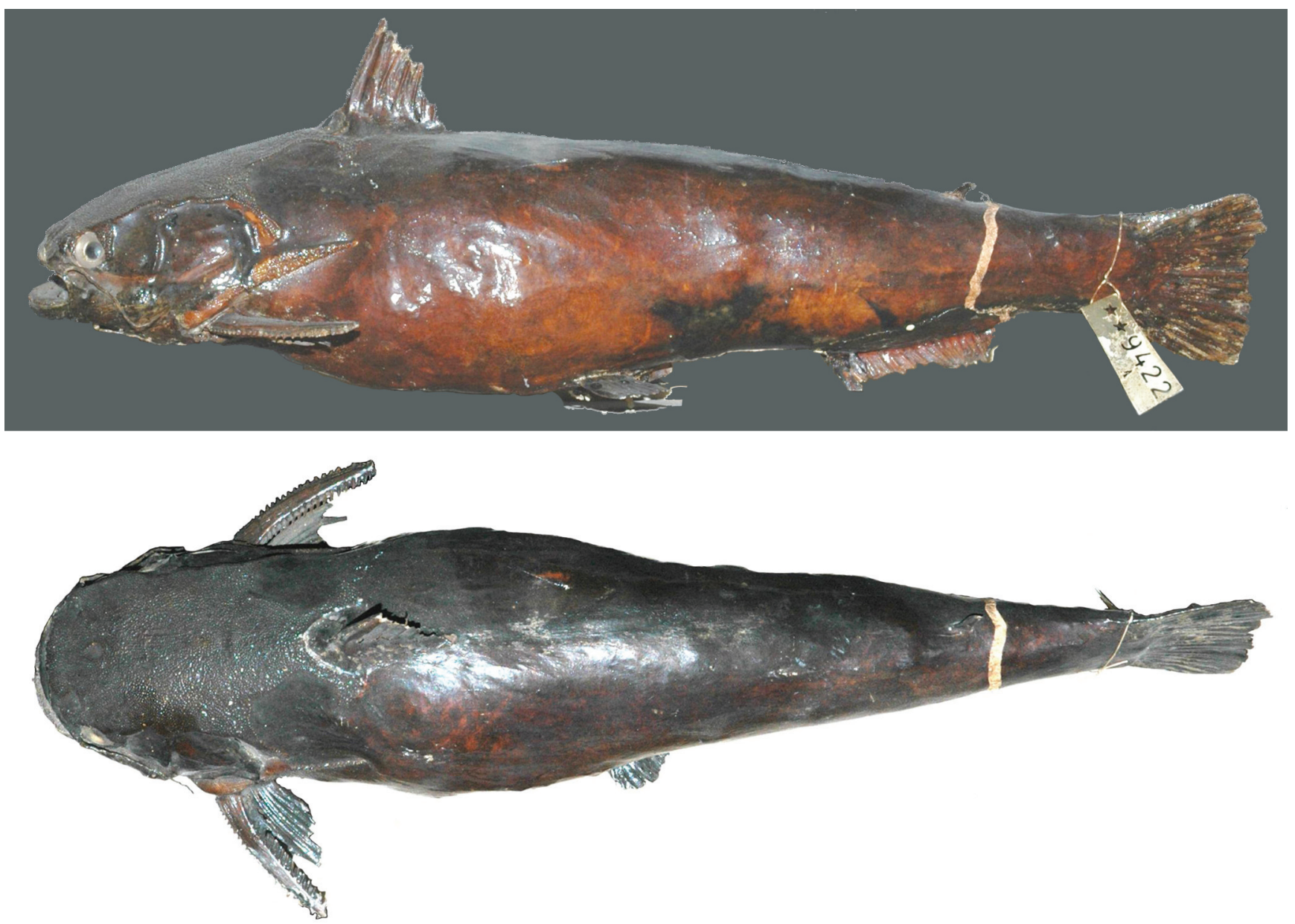

Fig. 4. Trachycotystes trachycorystes, MNHN A. 9422, holotype, 235 mm SL. Lateral view.

transferred as spoils of war to the Jardin des Plantes in Paris (Myers, 1964). The fish was collected during an expedition conducted from 1783 to 1792 by Brazilian naturalist Alexandre Rodrigues Ferreira who explored the rivers of the Amazon and Paraguay basins, Brazil. The type locality of $T$. trachycorystes can be considered the Amazon basin, Brazil, as this species is unknown from the Paraguay basin. Trachycorystes trachycorystes (possibly the holotype specimen) was drawn by one of Ferreira's artists and is figured in his "Viagem Filosófica" (Ferreira, 1971: pl. 27) under the common name "cabeça-de-ferro" (iron head).

Material examined. All from Brazil. Trachycorystes trachycorystes. MNHN A. 9422, holotype, 235 mm SL. Amazonas: MZUSP 7381, 2, 133-108.6 mm SL, igarapé Limãozinho, Maués, 4 Dec 1967, EPA (H. A. Britski); MZUSP 31322, 1, $246.6 \mathrm{~mm} \mathrm{SL}$, rio Negro, just downstream of mouth of rio Daraá, 00³0'S 64'40'W, 16 Feb 1980 , M. Goulding; MZUSP 52079, 1, Vista Escura, Tefé, 31 Jul 1979, Michael Goulding; MZUSP 52080, 5, rio Tefé, Supiã-Pucu (Xavascal), 29 Jul 1979, M. Goulding; MZUSP 52081, 2, 124.3 mm SL, alc., $221 \mathrm{~mm} \mathrm{SL}$, sk), rio Tefé, lago Mucura, 30 Jul 1979, M. Goulding; MZUSP 52091, 2, rio Negro at mouth of rio Arirará,
28 May 1979, Michael Goulding; MZUSP 52092, 2, Cachoeira do

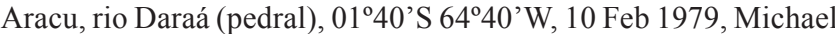
Goulding; MZUSP 52093, 2, rio Arirará, 10³0'S 63⒋' W, 8 Oct 1979, Michael Goulding; MZUSP 59093, 1, 220.5 mm SL, rio Negro, Ilha Mari-Mari, 31 May 1979, M. Goulding; MZUSP 52094, 1, rio Negro, Cachoeira de São Gabriel, Apr-May 1980, Michael Goulding; MZUSP 52095, 3, São Pedro, upper rio Negro, at mouth of igarapé do Ibará, 23 May 1979, Michael Goulding; MZUSP 108575, 1, $125.4 \mathrm{~mm}$ SL, rio Negro, Marautá (igapó), 27 May 1979, Michael Goulding; MZUSP 93463, 1, 110.7 mm, rio Tiquié, comunidade Pirarara-Poço, rio Negro drainage, $00^{\circ} 08^{\prime} 40^{\prime \prime} \mathrm{N}$ 69¹2'41'W. 19-20 Nov 2006, Flávio C. T. Lima et al.; MZUSP 103386, 1, $155.8 \mathrm{~mm}$ SL, igarapé Sirinau, bank of rio Cuieiras, about $25 \mathrm{~km}$ from its mouth, $02^{\circ} 42^{\prime} \mathrm{S} 60^{\circ} 20^{\prime} \mathrm{W}$, rio Negro drainage, Manaus, 30 Jan 1977, Alpha Helix Amazon Expedition; MZUSP 104547, 1, 188 mm SL, sk, no data; MZUSP 104673, 1, $190.7 \mathrm{~mm}$ SL, Fortaleza, Paraná de Urariá, 27 Feb 1972, EPA(P. E. Vanzolini); MZUSP 104674, 2, 186.9-208.8 mm, igarapé near Moura, rio Negro drainage, $01^{\circ} 27^{\prime}$ S $61^{\circ} 38^{\prime} \mathrm{W}$, EPA (P. E. Vanzolini). Pará: MZUSP 15690, 1: $142.1 \mathrm{~mm}$, igapó do lago Leonardo, Reserva Biológica de Trombetas, rio Trombetas, 14 Jul 1979, R. M. C. Castro. Trachycorystes cratensis. MNRJ 947, holotype, $60.6 \mathrm{~mm} \mathrm{SL}$, Grangeiro, Crato, Ceará, Antenor L. de Carvalho. 


\section{Acknowledgements}

Leandro M. Sousa prepared the photographs of Trachycorystes menezesi and of the gas bladders of the new species and T. trachycorystes. José L. O. Birindelli prepared the map of the region of Aripuanã. Naércio A. Menezes read the manuscript and presented a series of important suggestions to improve it. We are especially grateful to Mark H. Sabaj-Pérez (ANSP) for invaluable comments and corrections to the manuscript and for sending the photographs of Trachycorystes trachycorystes (Fig. 4) prepared by Mélyne Hautecoeur. Wolfgang J. Junk sent to MZUSP the bulk of specimens that facilitated description of the new species. We also thank the people mentioned in the Introduction who participated in the INPA trip to rio Aripuanã in November 1976. We are grateful to Paulo A. Buckup (MNRJ) for making possible the loan of the type specimen of Trachycorystes cratensis. This study has benefited from grants to H. A. B. from the Conselho Nacional de Desenvolvimento Científico e Tecnológico (CNPq) and to A. A. from the Fundação de Amparo à Pesquisa do Estado de São Paulo (FAPESP).

\section{Literature Cited}

Akama, A. 2004. Revisão sistemática dos gêneros Parauchenipterus Bleeker, 1862, e Trachelyopterus Valenciennes, 1840 (Siluriformes, Auchenipteridae). Unpublished Ph.D. Dissertation, Departamento de Zoologia, Instituto de Biociências da Universidade de São Paulo, 375p.

Birindelli, J. L. O., L. M. Sousa \& M. H. Sabaj Pérez, 2009. Morphology of the gas bladder in thorny catfishes (Siluriformes: Doradidae). Proceedings of the Academy of Natural Sciences of Philadelphia, 158: 261-296.

Bleeker, P. 1858. De visschen van den Indischen Archipel. Beschreven en toegelicht. Siluri Acta Societatis Regiae Scienciarum IndoNeêrlandicae, v. 4: i-xii + 1-370.

Cuvier, G. \& A. Valenciennes 1840 (Nov.). Histoire naturelle des poissons, volume 15. Paris: Pitois-Levrault. i-xxxi +540p., 421455 pls.
Ferraris, C. J., Jr. 2007. Checklist of catfishes, recent and fossil (Osteichthyes: Siluriformes), and catalogue of siluriform primary types. Zootaxa, 1418: 1-628.

Ferraris, C. J., Jr. \& R. S. Vari. 1999. The South American genus Auchenipterus Valenciennes, 1840 (Ostariophysi: Siluriformes: Auchenipteridae): monophyly and relationships with a revisionary study. Zoological Journal of the Linnean Society, 126: 338-450.

Ferreira, A. R. 1971. Viagem Filosófica pelas capitanias do Grão Pará, Rio Negro, Mato Grosso e Cuiabá, 1783-1792. Conselho Federal de Cultura, Rio de Janeiro, Iconografia, 2, Zoologia: 168pls., 13p., 1 map.

Garavello, J. C. 1988. Three new species of Parotocinclus Eigenmann \& Eigenmann, 1889 with comments on their geographical distribution (Pisces, Loricariidae). Naturalia, 13: 117-128.

Géry, J. \& W. Junk. 1977. Inpaichthys kerri n.g. n.sp., um novo peixe caracídeo do alto rio Aripuanã, Mato Grosso. Brasil. Acta Amazônica, 7: 417-422.

Greenfield, D.W. \& G. S. Glodek. 1977. Trachelyichthys exilis, a new species of catfish (Pisces: Auchenipteridae) from Peru. Fieldiana Zoology, 72: 47-58.

Kullander, S. O. 1995. Three new cichlid species from southern Amazonia: Aequidens gerciliae, A. epae and A. michaeli. Ichthyological Exploration of Freshwaters, 6: 149-170.

Myers, G. S. 1964. A brief sketch of the history of ichthyology in America to the year 1850. Copeia, 1964: 33-44.

Reis, R. E., S. O. Kullander \& C. J. Ferraris Jr. 2003. Checklist of the Freshwater Fishes of South and Central America. Porto Alegre, Edipucrs, 742p.

Sabaj-Pérez, M. H. 2010. Standard symbolic codes for institucional resource collection in herpetology and ichthyology: an Online Reference. Version 2.0 (8 November 2010). Electronically accessible at: http://www.asih.org/. American Society of Ichthyologists and Herpetologists, Washington, DC.

Taylor, W. R. \& G. C. van Dyke. 1985. Revised procedures for staining and clearing small fishes and other vertebrates for bone and cartilage study. Cybium, 4: 108-118.

Accepted April 7, 2011

Published June 30, 2011 